\title{
ASSESSMENT OF THE RAPID IMMUNOCHROMATOGRAPHIC TEST AS A DIAGNOSTIC TOOL FOR NOROVIRUS RELATED DIARRHEA IN CHILDREN
}

\author{
Reza Gunadi Ranuh ${ }^{1,2}$, Alpha Fardah Athiyyah ${ }^{1,2}$, Deanty Ayu PA ${ }^{1}$, Andy Darma ${ }^{1,2}$, Dadik Raharjo ${ }^{2,5}$, \\ Toshiro Shirakawa ${ }^{2,3,4}$, Subijanto Marto Sudarmo ${ }^{1,2}$ \\ ${ }^{1}$ Department of Child Health, Dr. Soetomo Hospital, Faculty of Medicine, ${ }^{2}$ Indonesia-Japan Collaborative \\ Research Center for Emerging and Re-emerging Infectious Diseases, Institute of Tropical Disease, Universitas \\ Airlangga, Surabaya, Indonesia, ${ }^{3}$ Division of Infectious Diseases, Department of International Health, Kobe \\ University Graduate School of Health Science, Kobe, Japan, ${ }^{4}$ Center for Infectious Diseases, Kobe University \\ Graduate School of Medicine, Kobe, Japan, ${ }^{5}$ Institute of Tropical Disease, Universitas Airlangga, Surabaya, \\ Indonesia
}

\section{ABSTRACT}

In developing countries, Norovirus is the second-leading cause of acute diarrhea, after rotavirus. The approved gold standard method for diagnosis of norovirus infection is RT-PCR. The rapid immunochromatographic test is a novel and expedient method for diagnosing norovirus that is relatively affordable. However, the use of the rapid immunochromatographic test remains controversial because of its accuracy. This study aimed to explore whether the rapid immunochromatographic test could be used for diagnosing norovirus-related diarrhea in children. Rapid immunochromatographic test (QuickNaviTMNorovirus2) and RT-PCR on stool samples was used to diagnose norovirus. Stool samples were obtained from pediatric patients aged between 1 and 60 months who had diarrhea and were admitted to the pediatric ward at Dr. Soetomo General Hospital Surabaya, between April 2013 and March 2014. Ninety-four subjects provided stool samples that were tested using QuickNaviTM-Noro2 and RT-PCR. Using the test, 64 samples tested positive for norovirus and 30 tested negatives. The sensitivity, specificity, positive predictive value, negative predictive value, and accuracy of the rapid immunochromatographic test were consecutively 90.3\%, 42.9\%, 43.8\%, 90\%, and 58.5\%. RT-PCR was used to test all samples to assess the accuracy, which showed that one from 31 samples contained the GI strain (1.1\%), while 30 samples (32\%) contained the GII strain. This study definitively establishes that the rapid immunochromatography test is not sufficiently accurate for use as a screening or diagnostic tool in norovirus-related diarrhea cases in children.

Keywords: Norovirus; rapid immunochromatographic test; RT-PCR

\section{ABSTRAK}

Di negara-negara berkembang, Norovirus adalah penyebab kedua diare akut setelah rotavirus. Metode standar emas yang disetujui untuk diagnosis infeksi norovirus adalah RT-PCR. Tes imunokromatografi cepat adalah metode baru dan bijaksana untuk mendiagnosis norovirus yang relatif terjangkau. Namun, penggunaan tes imunokromatografi cepat tetap kontroversial karena akurasinya. Penelitian ini bertujuan untuk mengeksplorasi apakah tes imunokromatografi cepat dapat digunakan untuk mendiagnosis diare terkait norovirus pada anak-anak. Tes imunokromatografi cepat (QuickNaviTM-Norovirus2) dan RT-PCR pada sampel tinja digunakan untuk mendiagnosis norovirus. Sampel tinja diperoleh dari pasien anak berusia antara 1 dan 60 bulan yang mengalami diare dan dirawat di bangsal anak di Rumah Sakit Umum Dr. Soetomo Surabaya, antara April 2013 dan Maret 2014. Sembilan puluh empat subjek memberikan sampel tinja yang diuji menggunakan QuickNaviTM -Noro2 dan RT-PCR. Menggunakan tes, 64 sampel dinyatakan positif norovirus dan 30 negatif. Sensitivitas, spesifisitas, nilai prediksi positif, nilai prediksi negatif, dan keakuratan tes imunokromatografi cepat berturut-turut 90,3\%, 42,9\%, 43,8\%, 90\%, dan 58,5\%. RT-PCR digunakan untuk menguji semua sampel untuk menilai akurasi, yang menunjukkan bahwa satu dari 31 sampel mengandung galur GI (1,1\%), sementara 30 sampel (32\%) berisi galur GII. Studi ini secara definitif menetapkan bahwa tes imunokromatografi cepat tidak cukup akurat untuk digunakan sebagai skrining atau alat diagnostik dalam kasus diare terkait norovirus pada anak-anak.

Kata kunci: Norovirus; uji imunokromatografi cepat; RT-PCR

Correspondence: Alpha Fardah Athiyyah, Jl. Medokan Semampir Indah I/2, Surabaya, Jawa Timur, Indonesia. Phone:+628123585507. E-mail: alpha-f-a@fk.unair.ac.id

pISSN:2355-8393 • eISSN: 2599-056x • doi: http://dx.doi.org/10.20473/fmi.v55i1.12557

- Fol Med Indones. 2019;55:48-53 • Received 31 Dec $2018 \bullet$ Accepted 21 Feb 2019

- Open access under CC-BY-NC-SA license • Available at https://e-journal.unair.ac.id/FMI/ 


\section{INTRODUCTION}

In developing countries, Norovirus is the secondleading cause of acute diarrhea, after rotavirus (Patel et al 2008). Moreover, norovirus is the pathogen most frequently responsible for episodes of acute gastroenteritis in children aged 3-5 years (Hall et al 2012, Atmar \& Estes 2006). Norovirus infection is more prevalent than rotavirus infection due to extensive rotavirus vaccination.(Atmar and Estes, 2006) Norovirus has led to the deaths of more than 200,000 children below the age of 5 in developing countries over the past two decades (Hall et al 2012). The Center for Disease Control and Prevention reported that norovirus cases accounted for more than $46 \%$ of all diarrhea cases with at least 23 million infections occurring in America each year.(Hall 2011, Hall et al 2012, CDC 2016) A study performed in Indonesia found norovirus in 31 out of 102 stool samples (Subekti et al 2002)

To date, seven norovirus genogroups (GI-GVII) have been successfully identified. GI and GII are the most common strains and are found in many studies (Zhuo et al 2017). It is vital to identify the norovirus strain and genus early in the diagnostic period as it allows for the pathogenesis of each case to be predicted leading to better and more personalized treatment. Norovirus diversity, and infection rates present many challenges for the immediate and appropriate detection of the virus for health practitioners.

Norovirus is detected by checking stool samples using reverse transcriptase-polymerase chain reaction (RTPCR), real-time PCR, enzyme-linked immunosorbent assay, and electron microscopy. The approved gold standard method for diagnosis of norovirus infection is RT-PCR (Atmar \& Estes 2001). The rapid immunochromatographic test is a novel and expedient method for diagnosing norovirus that is relatively affordable. However, the use of the rapid immunochromatographic test remains controversial because of its accuracy. The development of this method has led to the production of a new device called the QuickNaviTM-Noro2 which can give results in 1530 minutes (Saito et al 2014) The study, which used QuickNaviTM-Noro2 kits to perform immunochromatographic tests on 172 stool samples, reported $92 \%$ sensitivity and $98.3 \%$ sensitivity, respectively with test accuracy as high as $94.2 \%$ (Saito et al 2014). Another study in Japan, which examined 50 stools from children using three types of rapid immunochromatographic test (ImmunoCatch-Noro, QuickNaviTM-Noro2, GE test Noro Nissui), found that the sensitivity and specificity of the tests were consecutively 96.7 and 100\%, 96.7 and 100\%, and 93.3 and $100 \%$ (Khamrin et al 2014).
This study aimed to assess if a rapid immunochromatographic test to diagnose norovirus in stool samples is applicable as a viable alternative in diagnosing norovirus infection in pediatric diarrhea cases.

\section{MATERIALS AND METHODS}

\section{Study design}

The study was designed to compare the rapid immunochromatographic test and RT-PCR, the gold standard diagnosis tool. The study was conducted at pediatric patients from the gastroenterology ward, Dr. Soetomo General Hospital and the Laboratory of Tropical Disease (ITD), Universitas Airlangga Surabaya from April 2013 until March 2014. The subjects of this study were patients, age 1-60 months who are fulfilled the inclusion criteria from the pediatric gastroenterology ward, Dr. Soetomo Teaching Hospital.

\section{Study population}

The inclusion criteria of this study were: age between 160 months; acute diarrheal symptoms (defecation more than three times per day with watery consistency for less than 14 days), with written informed consent from the parents. Samples would be excluded from further testing if the amount of stool was insufficient for the test. Stool samples were collected and RT-PCR then performed following stool samples collection in which the result is visualized through gel electrophoresis.

\section{Laboratory tests}

QuickNavi'TM-Noro2 (Denka Seiken Co., Ltd) was used to perform the immunochromatography test in this study and norovirus diagnosis was confirmed using reverse transcriptase PCR (RT-PCR) methods. To extract norovirus, the Viral Nucleic Acid Extraction Kit II (Geneaid Biotech Ltd., New Taipei - Catalogue No. VI050/100/300) was used. RT-PCR was performed using the Invitrogen ThermoScript RT-PCR System (Invitrogen Life Technologies, USA, Product Code. 10155132) and primary-single oligonucleotides specific for G1SKF (5' CTGCCCGAATTYGTAAATGA 3'), G1SKR (5' CCAACCCARCCATTRTACA 3'), G2SKF (5' CNTGGGAGGGCGATCGCAA 3'), and G2SKR (5' CCRCCNGCATRHCCRTTRTACAT 3') (Kojima et al 2002). Gel electrophoresis was done by using Sigma-Aldrich agarose gel (Catalogue No. P5722). All process from nucleic acid extraction, RT-PCR, and electrophoresis was done at The Institute of Tropical 
Disease of Universitas Airlangga laboratory. The results were statistically analyzed.

\section{Statistical analysis}

The results were analyzed using $2 \times 2$ tables. Analysis include measuring the sensitivity, specificity, positive predictive value, negative predictive value, probability ratio, and pretest probability.

\section{RESULTS}

Samples were collected in the pediatric wards of Dr. Soetomo General Hospital Surabaya. There were 95 subjects recruited for the study. One subject was excluded because the stool sample volume was insufficient for examination. All of the remaining 94 samples were tested for norovirus using the rapid immunochromatography test. Using the rapid immunochromatography test 64 samples were positive for norovirus and 30 were negative. Of the 64 samples that tested positive by rapid immunochromatography, further testing using RT-PCR method revealed that only 28 were truly positive for norovirus. Therefore, of the 64 samples that tested positive by rapid immunochromatography 36 were false positives as they tested negative using the gold standard of RT-PCR. The 30 samples that produced negative results in the rapid immunochromatography test were also tested using RTPCR and three of them were positive for norovirus and the remaining 27 samples were truly negative (Figure 1). The demographic characteristics of the ninety-four subjects that were included in the study were then analyzed (Table 1).
Norovirus was identified in 64 subjects (68\%). Norovirus was mostly found in the 6-12-month age group, and the least in the 24 months or older age group which accounts for $5 \%$ of the samples. Most subjects have a good nutrition status $(72.3 \%)$, and those who were wasted and severely wasted accounted for 19 and $9 \%$ of the sample population, respectively. A total of 20 subjects $(21 \%)$ had or were currently being breastfed. Only $8(9 \%)$ of the subjects had never been breastfed. The majority of the subjects were exposed to breastfeeding and formula milk (66 subjects, $70 \%$ ).

All data related to gastrointestinal symptoms experienced by the subjects were analyzed to identify the characteristics of diarrhea and accompanying symptoms (Table 2).

Table 1. Demographic characteristics

\begin{tabular}{cc}
\hline \multicolumn{1}{c}{ Variable } & $\begin{array}{c}\text { Subjects } \\
(\mathrm{N}=94)\end{array}$ \\
\hline Age (months) & $18(19)$ \\
$1-5$ & $57(61)$ \\
$6-12$ & $14(15)$ \\
$13-24$ & $5(5)$ \\
$>24$ & \\
Gender & $58(62)$ \\
Male & $36(39)$ \\
Female & \\
Nutrition Status & $68(72)$ \\
Normal & $18(19)$ \\
Wasted & $8(9)$ \\
Severely Wasted & \\
Breastfeeding Status & $8(9)$ \\
Never & $66(70)$ \\
Breastfeeding \& formula milk & $20(21)$ \\
Breastfeeding only
\end{tabular}

Table 2. Clinical characteristics

\begin{tabular}{lccc}
\hline \multicolumn{1}{c}{ Parameter } & Sample (n=94) & Median & Range \\
\hline $\begin{array}{l}\text { Diarrhea duration (days) } \\
\text { Diarrhea frequency/24 h }\end{array}$ & & 2 & $1-4$ \\
Vomiting, n (\%) & $60(64 \%)$ & 5 & $1-15$ \\
Vomiting duration (days) & & 1 & $0-8$ \\
Vomiting frequency/24 h & $56(60 \%)$ & 2 & $0-10$ \\
Fever & & 2 & $0-14$ \\
Fever duration (days) & $59(63 \%)$ & & \\
Diarrhea type, n (\%) & $23(25 \%)$ & & \\
$\quad$ Watery & $6(6 \%)$ & & \\
$\quad$ Loose & $6(6 \%)$ & & \\
$\quad$ Bloody & & & \\
$\quad$ Mucoid & $2(2 \%)$ & & \\
Dehydration, n (\%) & $88(94 \%)$ & & \\
$\quad$ Without dehydration & $4(4 \%)$ & & \\
Mild-moderate & & & \\
Severe & & & \\
\hline
\end{tabular}


Table 3. Rapid immunochromatographic test in diagnosing norovirus-related diarrhea

\begin{tabular}{lcc}
\hline Variable & Value (\%) & $95 \%$ confidence interval \\
\hline Sensitivity (\%) & 90.3 & $85.1-95.5$ \\
Specificity (\%) & 42.9 & $37.6-48.1$ \\
Positive predictive value (\%) & 43.8 & $40.8-46.7$ \\
Negative predictive value (\%) & 90 & $81.9-98.0$ \\
Positive Likelihood ratio & 1.6 & $1.0-4.2$ \\
Negative Likelihood ratio & 0.23 & $0.2-1.7$ \\
\hline
\end{tabular}

The average duration of the diarrhea was two days. The mean frequency of diarrhea was five times in 24 hours. Subjects also experienced vomiting and fever. The average duration of vomiting was two days and the frequency were twice in 24 hours. Watery diarrhea (63\%) was the most common type of diarrhea. Most subjects $(94 \%)$ experienced mild-moderate dehydration while experiencing diarrhea.

All stool samples were tested using rapid immunochromatography method and the result was compared with those obtained by performing the RTPCR test. There are 94 examined samples. There are 28 positive results in both RT-PCR and immunochromatography. 27 results are true negative. Only three samples were false negative for immunochromatography. However, as much as 36 samples were detected false positive.

This study used an RT-PCR test with a single primer to screen for GI and GII strains of norovirus. Based on norovirus genogroup identification, GI was found in one sample (1\%) and GII in 30 samples (32\%). Using the results obtained in this study, diagnostic tests value of immunochromatography were analyzed using SPSS 20.0. (Table 3).

\section{DISCUSSION}

The subjects of this study were pediatric patients in the gastroenterology ward in the Dr. Soetomo General Hospital aged 1-60 months who fulfilled the inclusion criteria. There were 94 subjects who were recruited for the study. The proportion of subjects with norovirusrelated diarrhea was highest in the 6-12-month age group with 57 samples $(60.6 \%)$. This finding differs from that of Oldak et al, who showed that the incidence of norovirus or rotavirus-related diarrhea was highest in the 11-23 months age group accounting for 50 and $60 \%$ of the study populations, respectively (Oldak et al 2012)

All stool samples were tested using the QuickNaviTM_ Noro2 kit and RT-PCR to detect the presence of norovirus. There were 64 samples that tested positive for norovirus using the rapid immunochromatography test and 30 samples that tested negative. All samples were re-tested using the proven RT-PCR method. Three samples $(10 \%)$ that were negative for norovirus in the initial rapid immunochromatography test tested positive for norovirus when tested using RT-PCR. This result is similar to that of a previous study conducted in Japan where samples that were negative for norovirus in rapid immunochromatography testing turned out to be positive in RT-PCR test covered nine out of 68 samples (Khamrin et al 2014). This results supported the claim that immunochromatographic assay is good enough in detecting true positive sample.

The objective of this study was to determine the suitability of the rapid immunochromatography test as a diagnostic tool for norovirus through assessing sensitivity, specificity, positive predictive values, negative predictive value, probability ratio, and pretest probability. The sensitivity of this test was $90.3 \%$ and the specificity was only $42.9 \%$. In addition, the positive predictive value was $42.3 \%$, the negative predictive value was $90 \%$, and the accuracy value was only $58.5 \%$. A diagnostic test is classified as acceptable when the diagnostic parameters are high values. (Dahlan 2009, Sastroasmoro \& Ismael 2011).

Here, the sensitivity of rapid immunochromatography was at $90.3 \%$ indicating that as many as $90.3 \%$ of subjects with norovirus can be detected using this test. However, a specificity value of $42.9 \%$ indicates that only $42.9 \%$ of norovirus negative subjects could be detected using this immunochromatography test. Meanwhile, another study by Saito et al found that the sensitivity, specificity, and accuracy of this test were higher with values of $92.0 \%, 98.3 \%$, and $94.2 \%$, respectively (Saito et al 2014). In addition, the low positive predictive value obtained for this test (Table 3 ) indicates that the rapid immunochromatography test was unable to detect norovirus in true-positive samples. The high negative predictive value shows that this test was good enough identify the true-negative samples. Moreover, the low positive and negative likelihood ratios observed in our study indicate that the rapid immunochromatography test was unable to detect samples with positive or negative probabilities of norovirus presence. This is inconsistent with the findings of Khamrin et al, who obtained a positive predictive value of $100 \%$ for this test (Khamrin et al 
2014). However, this study reflected similar finding that stated possibility of false-positive and false-negative results should be considered (Kim \& Kim 2016).

It is possible that limitation of the rapid immunochromatography test in this study is due to its ability to identify whether cross-reaction is exists within this study. There's possibility that the low specificity, low positive predictive value, and low accuracy compared to the studies of Saito et al and Khamrin et al were occurred due to detection of unknown agents in our sample. The unknown agent can be bacterial or viral in origin, based on agents listed in product manual. Among all cross-reactive agents ever mentioned in the product manual, we highly suspect rotavirus as the major cause. This is based on study by Hakim et al which showed that rotavirus positive samples in several cities Indonesia was as high as $80 \%$ and as low as $37.5 \%$ during 1978-2015. The study also showed that during April-December 2013 in Surabaya, percentage of rotavirus positive sample was $40 \%$ (Hakim et al 2018). While unlikely, we also suspect that variation of norovirus genogroups may exists in our sample. This suspicion was supported by a study which confirmed that norovirus-specific monoclonal antibody, specifically NV23, is broadly reactive to 16 virus-like proteins from different genotypes of genogroup I, II, and IV (Kou et al 2015). These genogroups variants, while undefined by our RT-PCR due to only GI and GII which were examined, may have created cross reaction with the test. However, our study is limited in giving adequate evidence for any of those causes.

Based on the discussion about the possibility of crossreaction and several studies which supported the claim of high sensitivity and specificity (Saito et al 2014, Khamrin et al 2014), there is a suggestion that the differences between our result and prior studies were caused by the default sample preparation technique for QuickNavi ${ }^{\text {TM}}$-Noro2. Whereas, usage of stool sample managed to avoid cross-reaction with virus-like particle of ABH histo-blood antigen (Harrington et al 2002), the device's sample preparation uses diluted fecal swab material without any purification technique, as written in the device manual. Hence, in highly endemic population, non-norovirus agents may present in such material, thus may be detected by the device and yielding in high false positive result. This finally result in low specificity, low positive predictive value, and ultimately, low accuracy.

A test modality which showed low specificity does not have to be a bad test. If a test yields a very high sensitivity result, regardless of their specificity, it may be used as screening test for certain diseases (Sastroasmoro \& Ismael 2011). This view is supported by a study, in which ELISA kits was found to be useful for a preliminary screening, provided that ELISAnegative outbreaks will be re-tested by RT-PCR methods (de Bruin et al 2006).

This study showed that rapid immunochromatography test is not sufficiently accurate for use as a screening or diagnostic tool in norovirus-related diarrhea cases in children, especially in population where cross-reactive agents were suspected to exist. However, this study has limitations in defining the genogroups, in which only GI and GII was tested, and only by four kinds of specific primer. Moreover, this study only uses only one kind of immunochromatographic test. Hence, this study is inapplicable to other immunochromatographic tests which use different marking technique. Therefore, further study is needed to confirm the identity of these cross-reacting agents.

\section{CONCLUSION}

This study definitively establishes that the rapid immunochromatography test is not sufficiently accurate for use as a screening or diagnostic tool in norovirusrelated diarrhea cases in children.

\section{ACKNOWLEDGMENTS}

All authors acknowledge Universitas Airlangga and Kobe University for institutional support and program funding.

\section{REFERENCES}

Atmar RL, Estes MK (2001). Diagnosis of noncultivatable gastroenteritis viruses, the human caliciviruses. Clinical Microbiology Reviews 14, 1537

Atmar RL, Estes MK (2006). The Epidemiologic and clinical importance of norovirus infection. Gastroenterology Clinics of North America 35, 275290

de Bruin E, et al (2006). Diagnosis of Norovirus outbreaks by commercial ELISA or RT-PCR. Journal of Virological Methods 137, 259-264

CDC (2016). Norovirus.

Dahlan, M. (2009) Penelitian Diagnostik. Jakarta, Salemba Medika

Hakim MS, et al (2018). Significance of continuous rotavirus and norovirus surveillance in Indonesia. World Journal of Pediatrics. Childrens Hospital, Zhejiang University School of Medicine, (0123456789) 
Hall A (2011). Incidence of Acute Gastroenteritis and Role of Norovirus, Georgia, USA, 2004-2005. Emerging Infectious Diseases

Hall Aj, et al (2012). The roles of clostridium difficile and norovirus among gastroenteritis- associated deaths in the United States, 1999-2007. Clinical Infectious Diseases 55, 216-223

Harrington PR, et al (2002). Binding of Norwalk viruslike particles to $\mathrm{ABH}$ histo-blood group antigens is blocked by antisera from infected human volunteers or experimentally vaccinated mice. Journal of virology 76, 12335-43

Khamrin P, et al (2014). Comparison of three rapid tests for detection of norovirus in stool samples of acute gastroenteritis pediatric patients. Journal of Tropical Pediatrics 60, 481-483

Kim HS, Kim JS (2016). Discrepancies between Antigen and Polymerase Chain Reaction Tests for the Detection of Rotavirus and Norovirus. Annals of clinical and laboratory science 46, 282-5

Kojima S, et al (2002). Genogroup-specific PCR primers for detection of Norwalk-like viruses. Journal of Virological Methods 100, 107-114

Kou B, et al (2015). Characterization of cross-reactive norovirus-specific monoclonal antibodies. Clinical and vaccine immunology CVI 22, 160-7
Oldak E, et al (2012). Norovirus infections in children under 5 years of age hospitalized due to the acute viral gastroenteritis in northeastern Poland. European Journal of Clinical Microbiology \& Infectious Diseases 31, 417-422

Patel MM, et al (2008). Systematic literature review of role of noroviruses in sporadic gastroenteritis. Emerging Infectious Diseases 14, 1224-1231

Saito Y, Kato D, Inano K (2014). [Development of norovirus rapid detection kit "QuickNaviTMNorovirus2"]. Rinsho Biseibutsu Jinsoku Shindan Kenkyukai shi $=$ JARMAM. Journal of the Association for Rapid Method and Automation in Microbiology 24, 45-50

Sastroasmoro S, Ismael, S (2011). Dasar-dasar Metodologi Penelitian Klinis. 4th Ed. Jakarta, CV Sagung Seto

Subekti DS, et al (2002). Characterization of Norwalklike virus associated with gastroenteritis in Indonesia. Journal of Medical Virology 67, 253-258

Zhuo R, et al (2017). High genetic variability of norovirus leads to diagnostic test challenges. Journal of clinical virology: the official publication of the Pan American Society for Clinical Virology. Elsevier 96, 94-98 